\title{
Bob Chang Receives 1988 MRS Woody Award
}

MRS President Bob Chang was presented with the 1988 MRS Woody Award by Kathy Taylor, former MRS President, in recognition of Chang's outstanding achievements in the service of MRS, especially in the area of MRS international relations. The award was presented to Chang following the April 28, 1989 session of the MRS Council meeting.

The Woody Award was initiated by former MRS President Harry J. Leamy in 1984 and was named by him after its first recipient C.W. (Woody) White, the 1984 President of the Society. It is given to an MRS volunteer who, following the model established by White, devotes to MRS activities over an extended period of time a level of time and energy that considerably exceeds all reasonable expectations.

Chang's dedication to the Society over many years has led to numerous accomplishments. His association with MRS began in 1984 when with B. Abeles he organized the first symposium on "Plasma Synthesis and Etching of Electronic Materials." In 1986, with Carol Jantzen and Jim Roberto, he served as a Fall Meeting chair of the largest MRS meeting up to that time. Chang has been elected to several MRS offices. He was elected to MRS Council in
1986; in 1987 he was MRS Second Vice President and MRS First Vice president in 1988.

Since 1985, Bob Chang has been chairman of international relations, with the responsibility of assisting MRS-style activities around the world. He has been MRS's ambassador in developing a very special and fruitful relationship between the Society and the materials communities in Japan and China. Working with scientists in Japan he helped to organize the first MRS International Meeting on Advanced Materials, which was held in Japan in 1988. Also through Chang's efforts MRS cosponsored the International Conference on Electronic Materials and the Sixth IBMM (Ion Beam Modification of Materials) Conference.

Chang places international relations high on his MRS agenda. In accepting the award Chang said: "Today materials technology is moving extremely fast, and it is important for MRS to work with other societies to help our members keep up to date. MRS is in a very good position to serve our members and the international materials community through cooperation in the dissemination of research results and the exchange of new ideas." The Materials Re-

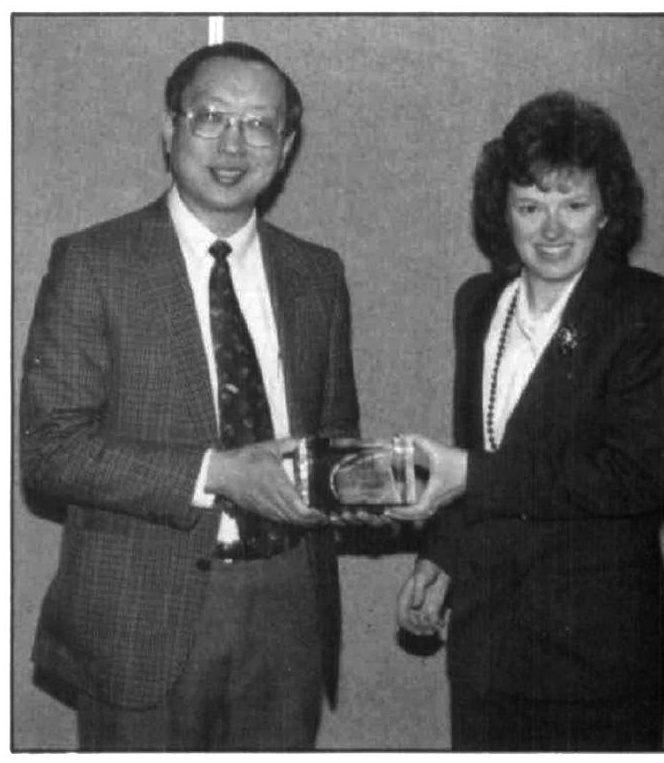

search Society attributes its success as a technical society to the dedication and hard work by many outstanding volunteers. Bob Chang exemplifies this devotion.

\section{MRS Re-Shapes Graduate Student Awards Program}

Starting with the 1989 MRS Fall Meeting the selection criteria for graduate student awards will be changed to include participation in a new graduate student symposium. This new symposium is being introduced to reflect the growing competitiveness of the graduate student awards program, a desire to improve the selection process, and to give more visibility to the graduate students at the meeting.

Award recipients at the upcoming Fall Meeting will be recognized at the Von Hippel Award Program on Wednesday evening, November 29, 1989. The first graduate student symposium during which graduate student award finalists will give short presentations on their work will be held Monday at noon, November 27, 1989 during the MRS Fall Meeting. A group of approximately 25 student award finalists, selected prior to the meeting, will be invited to participate in this symposium. The graduate student award selection subcommittee will be in attendance, and all meeting participants will be invited to attend as well.

Other award selection criteria include the following:

1. Graduate standing in a recognized academic program in materials science, metallurgy, ceramics, or polymers; physics or chemistry, geology or mineral science; electrical, civil, mechanical, mining, or nuclear engineering; or other materialsrelated field.

2. Participation in the 1989 MRS Fall Meeting as an attendee and author or coauthor of a symposium paper.

3. Outstanding performance in the conduct of a thesis project and promise for fu- ture substantial achievement in materials research as judged by the faculty advisor.

4. Significant and timely research results.

All finalists will receive a waiver of the meeting registration fee. Each award recipient will receive $\$ 250$, to be presented during the Von Hippel Award ceremony.

For application materials, write or call MRS Headquarters, $9800 \mathrm{Mc}$ Knight Road, Pittsburgh, PA 15237; telephone (412) 367-3003, fax (412) $367-4373$. The deadline for receipt of completed applications is September 1, 1989. Finalists will be notified October 2, 1989. 